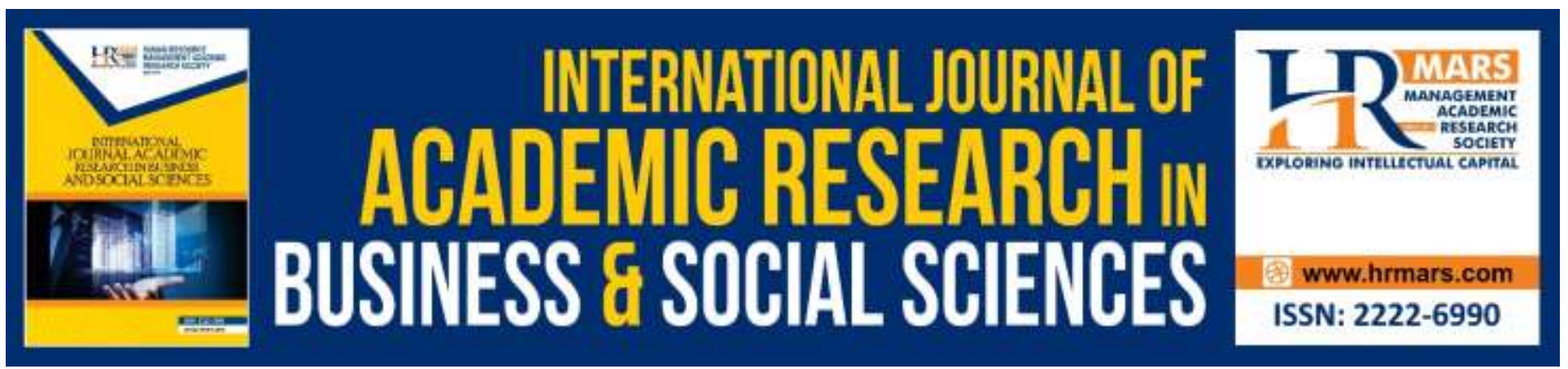

\title{
Utilizing Flow Chart in Writing Narrative Essay: English as Second Language Students' Perceptions
}

Melanie Selvaraj \& Azlina Abdul Aziz

To Link this Article: http://dx.doi.org/10.6007/IJARBSS/v10-i3/7017

DOI:10.6007/IJARBSS/v10-i3/7017

Received: 29 January 2020, Revised: 05 February 2020, Accepted: 22 February 2020

Published Online: 19 March 2020

In-Text Citation: (Selvaraj \& Aziz, 2020)

To Cite this Article: Selvaraj, M., \& Aziz, A. A. (2020). Utilizing Flow Chart in Writing Narrative Essay: English as Second Language Students' Perceptions. International Journal of Academic Research in Business and Social Sciencesn, 10(3), 1-16.

Copyright: @ 2020 The Author(s)

Published by Human Resource Management Academic Research Society (www.hrmars.com)

This article is published under the Creative Commons Attribution (CC BY 4.0) license. Anyone may reproduce, distribute, translate and create derivative works of this article (for both commercial and non-commercial purposes), subject to full attribution to the original publication and authors. The full terms of this license may be seen

at: http://creativecommons.org/licences/by/4.0/legalcode

Vol. 10, No. 3, 2020, Pg. 1 - 16

http://hrmars.com/index.php/pages/detail/IJARBSS

JOURNAL HOMEPAGE

Full Terms \& Conditions of access and use can be found at http://hrmars.com/index.php/pages/detail/publication-ethics 


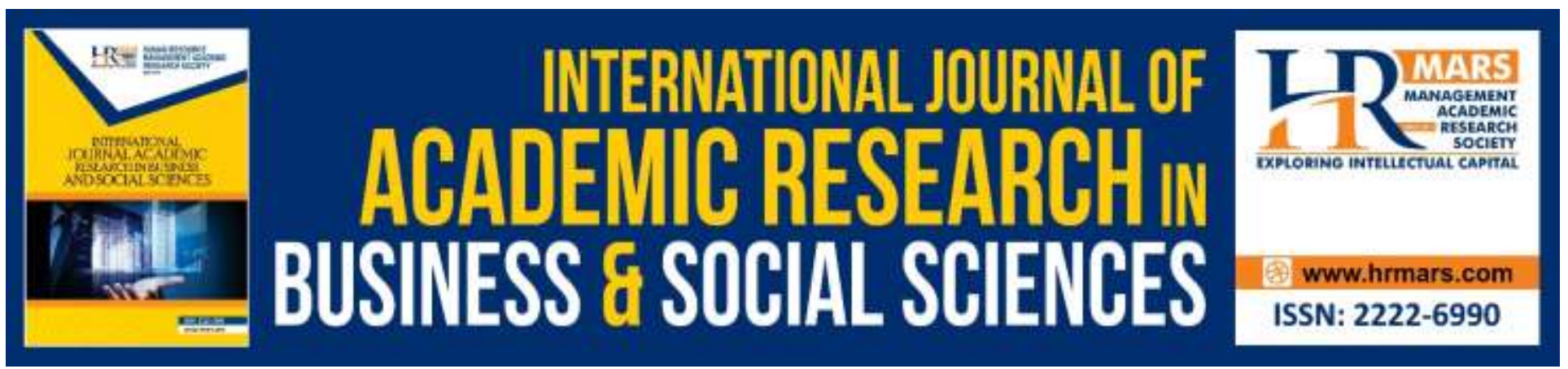

\title{
Utilizing Flow Chart in Writing Narrative Essay: English as Second Language Students' Perceptions
}

\author{
Melanie Selvaraj ${ }^{1} \&$ Azlina Abdul Aziz $^{2}$ \\ SK Tengku Mariam, Batu Pahat, Johor ${ }^{1}$, Fakulti Pendidikan, Universiti Kebangsaan Malaysia ${ }^{2}$ \\ Email: meljude5050@gmail.com, ${ }^{1}$ azlina1@ukm.my ${ }^{2}$
}

\begin{abstract}
Teaching and learning writing skills in English as a Second language classrooms has always been an issue despite various approaches and methods employed. Studies have shown mind mapping techniques has shown a significant improvement in improving students' writing yet at the primary school level, this issue was unresolved. This study focuses on students' perceptions after employing a flow chart technique in scaffolding students narrative writing. A semi-structured interview was adopted to find out students' perception in utilizing flow chart in producing narrative writing. Prior to the interview session, the participants were scaffolded their narrative writing process by utilizing the flowchart. The finding was thematically coded into two main sections namely, the effectiveness of teaching methods and the advantage and disadvantages of the technique. The findings show the participants were satisfied and found that the technique was easy to employ and useful as it improved their achievement in narrative writing. Besides that, students admitted that the teacher's scaffolding method and collaboration among peers was effective in the intervention process.
\end{abstract}

Keywords: Perception, Mind Mapping, Flow Map, Narrative, Writing Process

\section{Introduction}

The National Education Blueprint 2013-2025 emphasizes on mastery of English language among Malaysian students. It is penned that students should be proficient in both oral and written skills of the language. Hence, the four language skills, listening, speaking, reading and writing are given equal importance. Among these four skills, writing is regarded as a form of written communication which is unique as it promotes authors to express craft their ideas in creative means onto papers and readable by others. According to Nunan (2003) "writing involves mental works where ideas are created and thinking how to express, organize them into paragraphs so that it is comprehensible to readers".

To produce good comprehensible piece of writing, authors have to exercise four stages of writing process namely, pre-writing, drafting, revising and editing stages which involve thinking 
process and planning. Therefore, producing a piece of writing is a complex and demanding process. Yet, teaching and learning writing skills are prioritized for its significance in this globalization era. Writing skills is purposeful in various fields in the current world like in communication, business, education, culture and history thus posessing good writing skill is a demand in seeking career opportunities.

Apart from that, it is a necessary skill to be mastered by tertiary students to enable them to be an effective writer to enable them to communicate in written form or in other words producing an academic writing. Other than that, writing is important for students to promote their thinking skills, communication skills and develops creativity among students. Therefore, writing skills a prominent skill to be mastered by all regardless of native or non-native learners.

As for Malaysian students, English is a second language or at times the third language to be acquired. In this context, students in Malaysia, affront great challenges compared to native speakers in producing a good piece of writing. There are various challenges students meet during the composing process are such as lack of vocabulary, structural errors, due to mother tongue interference, grammatical errors and lack of coherence in the writing. Hence, writing can be daunting, challenging and frustrating for students in English as a Second Language (ESL) classrooms. Researchers and teachers have taken various measures to assist students to improve their writing skills from tertiary level to the elementary level, for instance, incorporating information and technology (ICT) and using mind mapping techniques to assist teaching and learning writing to face the world and improve student's achievement in writing examinations. Lim (2014) emphasized that it is "important for teachers to equip their students with writing skills to help students achieve success in national examinations, besides preparing students to be equipped for the workforce and the global economy". Thus, teaching students to produce a good writing is vital to equip students not only to pass their tests and examinations but it is a crucial tool to utilize the skill in social and fulfil the workplace requirement. Unfortunately with all these efforts the students writing performances are still at unsatisfactory level especially, for the primary school students. Therefore, this study focuses on improving primary school students. Previously, most studies have concentrated in tertiary and secondary education instead of on primary school level. Other than that, most intervention on writing skills are based on general mind mapping whereas this study specifically employs the flow map, which is more systematic and suitable to guide the novice writers in the classroom

\section{Problem Statement}

The Malaysian Education system has a great concern over the mastery of English Language among Malaysian citizens. In order to equip Malaysians with good command in both communication and written English, English is taught in early childhood to enable to practice writing for various purposes. Therefore, The Ministry of Education has made compulsory for the primary school pupils to learn English and sit for a standard assessment known as Primary School Assessment Test where writing is one of the components to be tested. Besides, writing a formatted essay, students are tested to compose a narrative writing based on the stimulus given. Studies shows, pupils in the primary school pupils, struggles to produce a comprehensible narrative story for various purposes such as unable to generate logical ideas, lacking in vocabulary and failing to write paragraphs with good coherence (Firmansyah, 2015). On the other hand, studies show that teachers' employ outdated teaching 
INTERNATIONAL JOURNAL OF ACADEMIC RESEARCH IN BUSINESS AND SOCIAL SCIENCES

Vol. 10, No. 3, March, 2020, E-ISSN: 2222-6990 C 2020 HRMARS

methods. Teachers expose students to memorization method where they are only concern on the end product rather than the process. Due to this, students get fewer chances to practice their writing in the classrooms. (Yunus and Chien, 2016) Nevertheless, it cannot be denied that writing is a difficult task which involves a complex process. Therefore, one of the means to scaffold students in producing a good piece of writing and provide students with the opportunity to go through the writing process is through utilizing flow map, which is a type of mind map.

\section{Purpose of the Study}

This paper aims to determine the perceptions of students in employing flow map in planning and drafting before producing a complete narrative writing.

\section{Objectives}

The objective of the research is to:

i) Determine the students' perceptions in employing flow chart in order to improve their narrative writing skills.

\section{Research Questions}

The research question is:

i) What are the students' perceptions in employing a flow map to improve their narrative writing?

\section{Literature Review \\ Narrative Writing}

Writing is defined as "one of the language skills which is used to communicate indirectly without having face to face interaction". (Namasivayam et al., 2017 p. 219). In other words, it a means of communication where writers get their ideas shared or delivered on a piece of paper. Writing can be regarded as putting a string of sentences, feelings or ideas in written form on a piece of paper. Teaching writing skills is vital as it develops thinking skills and communication skills. Other than that, student's vocabulary can be enriched through writing which is pivotal for future development. There are various genres of writing in teaching in English as a second language context and the prominent ones are expository, descriptive, narrative and persuasive. Each type of writing have its purposes and functions. In the second language writing classroom, narrative writing is a type of writing which is given importance as students begin to write in their early childhood. Narrative writing can be simply described as story writing. However, Bruner (1991) interprets narrative writing as an organization of writer's reminiscence or life experience which can be true or fiction which means imaginative. Narrative writing includes five important elements such as main character, plot, conflicts, setting and resolution. According to Riedal and Young (2010 p.219) plot is "the outline of main incidents in a narrative - that is structured to have a particular effect on the audience over time". The plot consists of five significant elements which are, introduction, rising, climax, falling and resolution. Therefore, to compose a good narrative writing, the key elements play a crucial role. 
INTERNATIONAL JOURNAL OF ACADEMIC RESEARCH IN BUSINESS AND SOCIAL SCIENCES Vol. 10, No. 3, March, 2020, E-ISSN: 2222-6990 @ 2020 HRMARS

\section{Process of Narrative Writing}

Every writing, irrespective of its genre, the process of writing cannot be eluded to accomplish an ideal piece of work. Seow (2002) has highlighted 4 basic writing stages; planning drafting, revising and editing and these stages are cyclical or recursive. The writing proses is important as it allows drafting, checking, refining and editing before producing the final product. Therefore, flowchart which is a type of mind map allows writers to plan their writing and editing before coming out with a complete piece of writing.

\section{Mind Mapping}

Mind mapping assists in composing writing ability among many ESL writers. Studies have shown using mind map among ESL learners have improved their writing skills. Mind mapping is a visual tool which promotes in ideas organization. (Budd, 2004) explains that a mind map is a graphic organizer in which the main classifications are viewed as sections of greater divisions from a key picture and lower classifications. (Buzan, 2006) reported mind mapping is capable of generating thoughts, taking notes, developing concepts and thoughts, and enhancing memory. Malaysian Ministry of Education collaborated with the National Innovation Agency or better known as AIM has introduced the i-think map which consists of eight I think maps. I-think map or innovative map was introduced in conjunction with the introduction of $21^{\text {st }}$ - century learning program in Malaysia. For this purpose, eight maps include a circle map, a bubble map, a double bubble map, a brace map, a tree map, a flow map, a multi-flow map and a bridge map identified and introduced to the students in primary and secondary students. These maps are believed to assists in promoting thinking skills and organizing ideas systematically. Hence, one of the maps introduced, the flow map is utilized to plan, draft and promote students in brainstorming ideas and organize them before composing a narrative story. In other words, a flow chart plays a key role in adopting the writing process.

\section{Benefits of Mind Map in Writing}

Mind mapping in writing benefits writers in various means especially "give assistance for students to start writing" (Suyanto, 2010 p.34: Saed and Omari, 2014; Agustriyanti, 2014). One of the significances of utilizing any type of mind mapping in developing writing is, it helps in brainstorming and organizing ideas mainly at the pre writing stage as writing needs planning before further development. "Mind maps can work as a tool to facilitate the learners to plan ideas in the pre-writing process" (Bukhari 2016, p.62). Hence, it motivates students to write. Apart from that mind mapping in teaching writing has proven that it develops creative thinking. It helps writers to brainstorm to increase their creativity when ideas are generated and organized cohesively.

Mind maps are a diagrammatic task or concept with at least a few words (King 2007), therefore it is beneficial to students who possess visual - spatial intelligence. Gardner (1992) argued, students with this intelligence learns through visual tools such as graphics and maps and chart. Hence mind map facilitates students with visual spatial learning styles to learn fast.

\section{Disadvantages of Mind Map}

Using mind map in writing classrooms has its shortcomings. A few studies have reported that, the participants believe that mind mapping is not suitable to learners as it is a challenging task to 
INTERNATIONAL JOURNAL OF ACADEMIC RESEARCH IN BUSINESS AND SOCIAL SCIENCES

Vol. 10, No. 3, March, 2020, E-ISSN: 2222-6990 @ 2020 HRMARS

transform the visuals to a linear text form as it involves great effort (Spoorthi et al. 2013). Moreover, developing a mind map needs prior knowledge of the subject or topics. (Davies2011) Therefore, study mastery of a topic is essential. Other than that, creating a mind map consumes time to master the mapping technique thus it can be a factor to demotivate students. (Vitulli and Giles, 2016)

\section{Past Researches}

Several studies were conducted in cooperating mind map in teaching writing skills in all level of teaching and learning writing skills in ESL classrooms and participants perception and experience were measured in using mind maps in learning writing. Fadillah (2019), investigated students' perceptions on advantages and disadvantages in employing mind map on writing classroom. The findings indicated that most of the subjects were positive and admitted that mind map assisted them in their writing especially in organizing ideas, developing and remembering the ideas developed. On the other hand, a group of subjects believed mind mapping has its disadvantages and pointed out it consumes time and lacking of internet access to create mind map in her study.

In another study, Yunus and Chien (2016) investigated students' perceptions on utilizing mind map for Malaysian University English Test or MUET. The 25 participants were the pre-university students in Malaysia responded, majority of them were positive in adopting the technique which enhances their writing skills mostly in planning their writing. They believed, by employing mind mapping technique, they understand the topics better and improved in writing creatively. Besides that, the findings showed, the participants aspired the mind mapping techniques to be integrated in writing classrooms.

Sovakandan, Jaganathan and Husain (2018) in their study on researching the perception of low-skill ESL students using I think Maps in writing processes reported, students writing anxiety level reduced and has enabled them to participate actively in completing the writing task. Hence it had promoted interest in their writing practices and improved in producing logical ideas in writing. Apart from that, a conclusion made that utilizing $\mathrm{i}$ - think maps in writing classrooms has great implication on the pedagogical aspect.

Another study which indicated the advantage in employing mind map in summary writing were investigated by Ravindranath, Abrew and Nadarajah (2016). It is reported that the medical students improved in writing summary by employing the flow charts. Therefore, the participants found that the use of mind map was useful in writing summaries although it is time consuming

Vijayavalsalan (2016); Alzgool (2019); Muhammad, Saoula, Issa \& Ahmed (2019) based on his research on essay writing in higher education noticed that mind map assists the participants to deduce the topics, brainstorm and increase participants' creativity in their essay writing. It is an effective tool to employ in the pre writing stage or planning stage. Moreover, participants responded that they could write effectively thus makes writing was amusing and enjoyable.

A study on "Impacts of a Mind Mapping-Based Contextual Gaming Approach on EFL Students' Writing Performance, Learning Perceptions and Generative uses in an English Course" by Fu et al. (2019); 
INTERNATIONAL JOURNAL OF ACADEMIC RESEARCH IN BUSINESS AND SOCIAL SCIENCES

Vol. 10, No. 3, March, 2020, E-ISSN: 2222-6990 C 2020 HRMARS

Khalid, Islam \& Ahmed (2019) verified, participants of the study considered mind map is interesting and has its benefits as it promotes ideas generating and helps in divergent thinking.

\section{Methodology \\ Research Design}

Qualitative research design is the research design identified for this action research. The objective is to analyze the attitudes of the participants towards the use of flowchart in the writing process, primarily in writing a narrative essay concentrating on both the material effectiveness, benefits and the approach to teaching.

\section{Participants}

The method of purposeful sampling was adopted to determine the research participants. The participants were from Year 4 urban primary school students who scored average results in their midterm writing examination. Other than that, the participants selected were from those who scored 0 to 18 marks in the Section C narrative writing task. The total score for this section is 25 marks. This is to ensure the results obtained to be bias-free. The total participants selected were 12 out of 25 participants who were involved in the action research in utilizing flow chart in order to produce anarrative writing.

\section{Method}

The data collection was performed through a semi-structured interview to retrieve data and information on the perception of the learners of using the flow chart in writing and the teaching strategy used in composing a narrative essay. "Interviews are a suitable way of collecting in-depth data about the views, ideas, perceptions and emotions of individuals" Easwaramoorthy and Zarinpoush (2006). Earlier, the participants were involved in a narrative writing intervention which was utilizing flow chart in writing in two-cycles consisting of 12 sessions. The interview was carried out after the post-test at the end of the second cycle. The results were analyzed, coded thematically to identify the response category and tabulated according to seven themes.

\section{Findings}

The findings of the semi-structured interview were thematically coded two main categories which are the effectiveness of materials, effectiveness of teaching method and advantages and disadvantages of utilizing flow chart. Later, they were structured into six themes based on the main categories namely, Understanding the concept of the flowchart, learning method preferred, Collaboration effectiveness, Scaffolding Effectiveness, Satisfactory, and advantages and disadvantages of the technique employed.

\section{i) Effectiveness of Materials}

a) Understanding the concept of the flow chart

During the interview session, students were questioned about the flow chart idea as an instrument to improve their writing process, 10 out of 12 students interviewed were able to define the map name used and describe the flow chart feature and the flowchart components. Students were able 
INTERNATIONAL JOURNAL OF ACADEMIC RESEARCH IN BUSINESS AND SOCIAL SCIENCES

Vol. 10, No. 3, March, 2020, E-ISSN: 2222-6990 @ 2020 HRMARS

to clarify each rectangle's features and the arrows and lines displayed in the flowchart where the linking words need to be inserted by the participants.

Interviewer Can you explain how to use the flow chart to write a narrative story?

Participant 12 Ermmm. In the flow chart, there are box for introduction. In introduction we need to put character, place and time. In the second box, we need to put sentences of picture 1. Then, kotak ketiga (the third box) sentences for picture 2, kotak keempat (fourth box) picture 3, kotak terakhir (the last box) picture 4.

Errmmm I have to write picture four moral values or lesson yang dipelajari (the lesson learnt from the incident)

Participant 05: $\quad$ Mula mula kena tulis character kat introduction dulu. Lepas tu cari linking words yang sesuai, lepas tu baru pergi dekat picture one. Lepas tu buat linking words lagi dan pergi ke picture two. Masukkan linking words lagi, baru pergi picture 3 and linking words dan buat ayat untuk picture 4 dan buat closure.

(At first, you have to write the character at the introduction. Then, find the linking words and write what's in picture one. Then write another linking word and write what's in picture two. Then, add the linking words and write what's in picture three and then write the sentences for picture and do the closure.)

Apart from that, the participant ensured that they will be able to explain and teach others as it is easy to use the template.

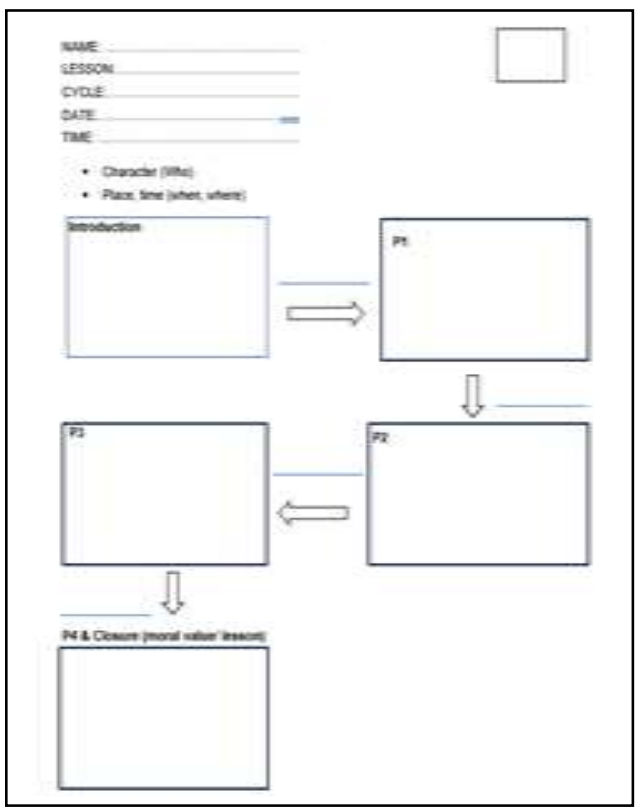

Figure 1: Flow chart template 
INTERNATIONAL JOURNAL OF ACADEMIC RESEARCH IN BUSINESS AND SOCIAL SCIENCES Vol. 10, No. 3, March, 2020, E-ISSN: 2222-6990 (C) 2020 HRMARS

\section{b) User friendly}

In addition, some participants stressed that using the flow chart to produce a narrative writing would be helpful as the arrows provided guidance on what to write for each panel or rectangle. They claim, the arrows are driving them to travel from one picture to another and the given panels which represent the pictures are ensuring that writers utilize them to write about all the pictures without missing any points as they are indicating the important events in the story In addition, they are sure not to miss linking words as the template prompts them to integrate linking words into their narratives, which is a key element in narrative writing to illustrate the transition from one idea to another. This justifies that the flow chart template is easy and helpful in composing narratives especially in guiding students to start writing their narrative story step by step. Therefore, participants go through the writing process subconsciously when utilizing the flow chart.Apart from that, the participants admitted that they can write longer essays proves that, flowchart help to generate ideas before writing a complete story.

Interviewer

Participant 2

Participant

08
Okay can you tell me, is it easy or difficult to use the flow chart? Senang atau susah nak guna?

It's easy. Sebab dah senang sikit..tengok gambar ikut arrow je. (It is easier now, I just have to look at the pictures and follow the arrows to write) Because got linking words, and arrows

\section{ii)Teaching methodology}

\section{a) Preference to flow chart technique}

In the interviewe, the participants showed preference to the teaching and learning method employed to learn writing a narrative story. The participants stated that it is user friendly tool to assist them to write a narrative essay unlike before. They believed using the flow chart technique is interesting and new to them. In brief, they affirmed that it is an interesting and new way to write stories using the flow chart. All the 12 students interviewed came to a term that this method is preferred compared to the traditional method used before. Based on the findings, it can be concluded that students preferred mind mapping technique to modelling method or better known as product-based approach methodology which has been applied all the while. Hence, it justifies that mind mapping method is an interesting method to employ in order to scaffold students writing skills in the ESL classroom.

Interviewer

Oh its easy.... Which method do you like. Let me explain. Last time when we learn Section C writing, I just give you pictures and you straightaway write the story. Now, you use the flow chart, before 
INTERNATIONAL JOURNAL OF ACADEMIC RESEARCH IN BUSINESS AND SOCIAL SCIENCES

Vol. 10, No. 3, March, 2020, E-ISSN: 2222-6990 @ 2020 HRMARS

writing a complete story. Which way do you like? Writing a story with a flow chart or without a flowchart?

Participant $01 \quad$ With a flowchart.

Interviewer Good.... Which method do you like? Let me explain. Last time when we learn Section C writing, I just give you pictures and you straightaway write the sentences on your own and then write the story. Now, you use the flow chart, before writing a complete story. Which way do you like? Writing a story with a flow chart or without a flowchart?

Participant 02 With a flowchart.

Interviewer Why you like it?

Participant $02 \quad$ Sebab dah senang sikit.tengok gambar ikut arrow je (It is easier now, I just have to look at the pictures and follow the arrows to write)

\section{b) Collaborative learning}

Despite all these points, another discovery made in the interview response is, the majority of the students agreed that collaborative learning during the intervention process did help them to improve their writing skills. They stated that they were assisted by the peer in various areas such as in sentences construction, giving the meaning of the words and also in correcting the wrong spellings. In addition, they admitted that group members coached them throughout the process and due to this they have improved in many areas such as enriching their vocabulary, improved in spelling particularly when it concerns the spellings of irregular verbs from their peer. Apart from that, participants stated they have improved in constructing sentences and composing their narratives with ideas contributed by their group members. Besides that, the participants believed that they are comfortable working with peers and able to complete the task with their help. This had allowed the development of individual bonding and working towards achieving the goals. Hence, it can be concluded that collaboration through group work supports students emotionally, socially and cognitively.

$\begin{array}{ll}\text { Interviewer } & \text { Oh, in groups? Do your friends help you? } \\ \text { Participant 02 } & \text { Yes. } \\ \text { Interviewer } & \text { Okay, how do they help you? } \\ \text { Participant 02 } & \begin{array}{l}\text { Aaa.. spellingkan ejaan. (tell the correct spelling) kadang kadang... } \\ \text { tukar BM ke English (sometimes they help to translate Bahasa }\end{array} \\ & \text { Melayu to English. } \\ \text { Interviewer } & \text { Do they give some ideas to write? } \\ \text { Participant 02 } & \begin{array}{l}\text { Yes, got. Ada sekali tu saya tak tahu macam mana nak tulis moral } \\ \text { value. Chloe ajar. (There was once I wasn't sure how to write the } \\ \text { moral value.. Chloe taught me.) }\end{array}\end{array}$


INTERNATIONAL JOURNAL OF ACADEMIC RESEARCH IN BUSINESS AND SOCIAL SCIENCES Vol. 10, No. 3, March, 2020, E-ISSN: 2222-6990 @ 2020 HRMARS

\section{c) The effectiveness of Scaffolding}

During the intervention the participants were scaffolded throughout the process, Students were prompted with questions for each task given. Besides that, a list of linking words was given to help them to enhance their writing skills. Other than that, students also were given list or words associated with the themes given. The findings to questions asked whether these approaches were helpful, all the participants strongly agreed that it helped them through the writing process extremely. Majority of the students agreed that scaffolding provided through the method of teaching, materials and resulted in success in learning and improving their writing skills. Indirectly the scaffolding process, motivated the learners, reduced their anxiety and lessened the frustration in learners.

Interviewer

Participant 02

Interviewer

Participant 02
Okay, how did teacher help you in the classroom?

Teacher bagi linking words..I pilih. Aaaa..ada word list. Saya buat ikut tu.( teacher gave linking words lists and I just choose. There is also word list. I write according to it ).

Do you get any other help like meaning or words and extra words to help to write?

Yes..ada.. dulu saya tak tahu maksud, sekarang dah tahu sikit sikit..tapi kadang lupa. ha ha ha ..There is, last time I don't know the meaning of some words but now I know some. But.. sometimes I forget. Ha ha ha)

\section{d) Students' Satisfactory}

Obviously in the interview, the participants showed their satisfactory by admitting, they have improved and obtained a high score in the tests compared to pre-test administered. In addition, the participants confessed that they could write better sentence especially in expanding short sentences to long sentences. Based on the analysis, the sentences developed in the Cycle 2 post-test, the findings show participants constructed more compound sentences compared to the pre-test output where more simple sentences were identified. Almost all the participants interviewed indicated that their story has become lengthier. Besides, various sentences patterns constructed, participants improved tremendously is in describing the character or the lead by connecting to main ideas of the story and the use of linking words showed a good coherence between paragraphs and events. Therefore, the scored obtained increased and this has satisfied the participants towards the use of flow chart in scaffolding their narrative writing.

\author{
Interviewer \\ Participant 06 \\ Interviewer \\ Participant 06 \\ Interviewer \\ Participant 06
}

Interviewer
Okay. Do you think you have improved in your writing?

Ada peningkatan tak? (Any improvement?)

Yes.

How you know, you have improved?

I can make a long story and my marks........

Your marks?

Masa ujian yang last meningkat. My marks increased in the last test

Oh! How, err how you improved? Mana kamu tahu kamu ada

peningkatan? (How do you know you have improved? 
INTERNATIONAL JOURNAL OF ACADEMIC RESEARCH IN BUSINESS AND SOCIAL SCIENCES Vol. 10, No. 3, March, 2020, E-ISSN: 2222-6990 @ 2020 HRMARS

Participant $04 \quad$ Emm kalau dulu pendek pendek ayatnya sekarang dah Panjang panjang sebab dah ada linking words. Lepas tu, Karangan tak sampai 5 baris. Ha ha ha... emm. (Last time my essay is short but now I can write longer sentences using linking words. Then my essay was not more than 5 sentences. ha ha ha)

In line with this, students agreed, insertion of linking words or discourse markers plays a vital role in sequentially expanding a story thus lengthens the story as it assists writers to sequence each and every important event taking place in the story Apart from that, students improved in developing content paragraph structure and increased the length of their writing. At the same time, participants were confident that they will never fail their writing tests, thus shows there are satisfied and confident in composing a narrative writing using the flow chart in the future as they have experienced the benefits of employing the flow chart technique.

Another significant finding derived from the interview which shows the participants were satisfied with the idea of using the flow chart in composing a narrative story is based on their confessions on sharing the flow chart technique with others. To be specific. the participants agreed, they were satisfied based on several reasons besides the achievement attained in their post-test. They affirmed that layout of the flow chart, guides them to develop their writing with good coherence. The userfriendly flow chart, the peer collaboration and teachers teaching method has led them to produce better narratives has increased their satisfactory. As a result, the participants showed strong interest in employing the flow chart in the narrative writing process in the future and agreed to share the idea of employing flow chart in narrative writing to benefit others.

Interviewer Can you share or tell about the flow chart with others?

Participant $06 \quad$ Yes. I can.

Interviewer Whom you want share with?

Participant 06 With my friends and adik beradik (siblings)

Interviewer Can you share or tell about the flow chart with others?

Participant $04 \quad$ Yes

Interviewer Whom you want to share this technique to?

Participant $04 \quad$ My brother, sister and my cousin.

iii) Advantages and Disadvantages

Most of the students agreed that utilizing flow chart in the process of writing a narrative essay has its advantages. In general, students stated that, they were able to compose a lengthy essay, abled to use the linking words to make connections between the paragraphs. Students also emphasized that they have become a better writer as the pre and post test showed a very significant difference in the 
scores obtained. Apart from that, students admitted, the scaffolding and collaborative learning assisted them in improving their writing skills. However, there is a drawback identified form the participants' responses. In the total of 7 out of 12 students mentioned that, planning stage consumes more time thus they have to rush in completing the whole essay. However, some added, they became faster towards the end of the intervention period. Hence, it can be concluded, there was a time management issue at the beginning of the process and eventually they managed to overcome the issue as they get familiar with the flowchart function and had proven that they can complete writing the narrative story during the pre-test when participants could complete the test within the stipulated time..

PARTICIPANT $05 \quad$ Nak cari idea.(Looking for ideas).Tapi masa test sempat buat sebab buat sendiri.tak bincang dalam kumpulan.(But then during test test I had enough time because I wrote by myself, not in groups)

\section{Discussion and Implications}

Teaching and learning writing a narrative story among ESL learners is daunting to teachers due to various factors. The main focus of this paper is to identify the students' perception in using the flow chart in the process of producing a narrative essay. From the findings obtained from the semi structured interview, it is obvious that the utilizing the flow chart in the process of producing a story was helpful. The scaffolding process by utilizing flow chart indeed preferred by students as flow chart is a unique and most suitable type of mind map which gives directions to students to develop their narrative writing learning. Students believe the cooperative learning method employed in the classroom give new insights towards writing. They admitted that the blending of peer coaching and teachers scaffolding technique in the writing process play a significant role in assisting students to improve in their narrative writing skills. Guiding questions and more helping words are a necessity to enable students to write. Students are also motivated to share and disseminate the idea of utilizing the flowchart as a tool to scaffold their writing process with peers and family as they found the technique is simple and applicable.

This research gives implications various parties such as the ESL teachers. Undoubtedly, there are many writing pieces of research done on utilizing mind map in writing. However, very limited studies done on utilizing flow chart in narrative writing for primary school students. This will be useful to teachers in ESL classroom who face various challenges. Therefore, teachers can employ this technique to improve their students writing skills, especially in the primary school level.

The simplicity of technique is suitable to be employed by ESL learners may it be secondary or primary school students as in Malaysian examination, both primary and secondary students are tested in their narrative writing skills. By adopting this technique, students will be more motivated to write as the flowchart directs them and they can control students' own learning as they have a template to utilize whenever they need to produce a narrative writing may it be at home or school.

Above all, it is also beneficial to The Ministry of Education in boosting the overall achievement level in public examinations so that it can be parallel with the comprehension paper achievement. 


\section{Conclusion}

Based on the finding it can be concluded that students are positive towards using the flowchart in the process of planning narrative writing as it guides students step by step as they are novice writers. Students believe, the flow chart template is user-friendly and the scaffolding process contributed a significant improvement in composing narrative writing. Apart from that, they are confident that this technique can improve their writing skills and award them with good grades in writing a story when there is scaffolding from the teacher and collaboration with peers.Besides that, a good confidence level motivates students to engage in writing and stimultaneously improve their writing performance. Teachers need to employ flow charts compared to other graphic organizers in the teaching narrative writing to novice writers as these young writers have shown a great satisfactory in utilizing this graphic organizer. Hence, all primary students need to learn to use the flow chart to produce a well planned narrative writing. However, planning a narrative essay using a flow chart is time-consuming, therefore it is suggested teachers provide ample time and coaching during the planning stage until students master the technique.

Overall, in the field of writing, the uniqueness of flow chart may assist teachers to devise an appropriate learning approach.Therefore, this study creates awereness to teachers that utilizing flow chart assists novive writers as it guides tham step by step in producing a narrative writing among primary school students.

\section{References}

Agustrianti, S. (2014) improving the eleventh grade students'ability in writing simple cause effect sentences through flow chart. e-Journal of ELTS (English Language Teaching Society), 2(1).

Al Naqbi, S. (2011). The use of mind mapping to develop writing skills in UAE schools. Education, Business and Society: Contemporary Middle Eastern Issues, 4(2), 120-133.

Alzgool, M. (2019). Nexus between Green HRM and Green Management towards Fostering Green Values. Management Science Letters, 9(12), 2073-2082.

Al-Zyoud, A. A., Al Jamal, D., \& Baniabdelrahman, A. (2017). Mind mapping and students' writing performance. Arab World English Journal (AWEJ) Volume, 8.

Bruner, J. (1991). The Narrative Construction of Reality. Critical Inquiry, 18, 1-21.

Budd, John, W. (2004). Mind maps as classroom exercises. Journal of Economic Education, 35, 1, 35.

Bukhari, S. S. F. (2016). Mind Mapping Technique to Enhance EFL Writing Skill. International Journal of Linguistics and Communication, 4(1), 58-77.

Buzan, T., \& Buzan, B. (2006). The mind map book. Pearson Education.

Davies, M. (2011). Concept mapping, mind mapping and argument mapping: what are the differences and do they matter?. Higher education, 62(3), 279-301.

Fadillah, R. (2019). Students'perception on the use of mind mapping application software in learning writing. Celtic: A Journal of Culture, English Language Teaching, Literature, \& Linguistics, 6(1), 58-64.

Firmansyah, A. (2015). The Influence of Mind Mapping Technique and Students' Attitude toward Students' Ability in Writing a Recount Text of the Eighth Grade Students of State Junior High School 45 Palembang. RIPTEKSI KEPENDIDIKAN PGRI. 
INTERNATIONAL JOURNAL OF ACADEMIC RESEARCH IN BUSINESS AND SOCIAL SCIENCES Vol. 10, No. 3, March, 2020, E-ISSN: 2222-6990 @ 2020 HRMARS

Fu, Q. K., Lin, C. J., Hwang, G. J., \& Zhang, L. (2019). Impacts of a mind mapping-based contextual gaming approach on EFL students' writing performance, learning perceptions and generative uses in an English course. Computers \& Education, 137, 59-77.

Gardner, H. (1992). Multiple intelligences (Vol. 5, p. 56). Minnesota Center for Arts Education.

Heilmann, S. (2018). A Scaffolding Approach Using Interviews and Narrative Inquiry. Networks: An Online Journal for Teacher Research, 20(2), 3.

Khalid, N., Islam, D. M. Z., \& Ahmed, M. R. M. (2019). Sentrepreneurial Training and Organizational

Performance: Implications for Future. Humanities \& Social Sciences Reviews, 7(2), 590-593.

Mahudin, N. B. M., (2018). Improving form 1 students'skills in generating ideas for essay writing using circle and flee maps technique. Proceedings of International Conference on The Future of Education IConFEd) 2018, Institute of Teacher Education Tuanku Bainun Campus, Penang, Malaysia.

Muhammad, K., Saoula, O., Issa, M., \& Ahmed, U. (2019). Contract Management and Performance Characteristics: An Empirical and Managerial Implication for Indonesia. Management Science Letters, 9(8), 1289-1298.

Namasivayam, P., Singh, C. K. S., Mostafa, N. A., Janoory, L., \& Abdullah, M. S. (2017). Improving ESL students' descriptive writing through wh-question technique. International Journal of Academic Research in Business and Social Sciences, 7(7), 219-231.

Nunan D. (2003).Practical Language Learning Teaching. NY: Mcgrow-Hill Companies

Ravindranath, S., de Abrew, W. K., \& Nadarajah, V. D. (2016). Student's perception of mind mapping in Problem-based learning. J Contemp Med Edu, 4(2), 61.

Riedl, M. O., \& Young, R. M. (2010). Narrative planning: Balancing plot and character. Journal of Artificial Intelligence Research, 39, 217-268.

Saed, H. A., \& Al-Omari, H. A. (2014). The effectiveness of a proposed program based on a mind mapping strategy in developing the writing achievement of eleventh grade EFL students in Jordan and their attitudes towards writing. Journal of Education and Practice, 5(18), 88-109.

Seow, A. (2002). The writing process and process writing. Methodology in language teaching: An anthology of current practice, 315-320.

Slater, L. (2004). Collaboration: A Framework for School Improvement. International electronic journal for leadership in learning, 8(5), n5.

Sovakandan, H., Jaganathan, P., \& Husain, F. M. (2018). Investigating low proficiency ESL students' perception of the use of i-Think Maps in writing practices. Malaysian Journal of ELT Research, 14(2), 13.

Spoorthi, B. R., Prashanthi, C., \& Pandurangappa, R. (2013). Mind Mapping-an effective learning adjunct to acquire a tsunami of information. International Journal of Scientific and Research Publications, 3(12), 1-4.

Suyanto, A. (2010). The effectiveness of Mindmapping to Teach Writing Skill Viewed from Their IQ (An Experimental Study in the Seventh Grade Students of SMPN 1 Prambon in the Academic Year 2009/2010) (Doctoral dissertation, Universitas Sebelas Maret).

Vijayavalsalan, B. (2016). Mind mapping as a strategy for enhancing essay writing skills. The New Educational Review, 3(44), 137-150.

Vitulli, P., \& Giles, R. (2016). Mind mapping: Making connections with images and color. Delta Journal of Education, 6(2), 1-10. 
INTERNATIONAL JOURNAL OF ACADEMIC RESEARCH IN BUSINESS AND SOCIAL SCIENCES

Vol. 10, No. 3, March, 2020, E-ISSN: 2222-6990 @ 2020 HRMARS

Waloyo, E. (2017). The implementation of mind mapping technique in teaching writing: A case study at MAN 13 Jakarta. ELT Echo: The Journal of English Language Teaching in Foreign Language Context, 2(1), 72-83.

Yunus, M. M., \& Chien, C. H. (2016). The use of mind mapping strategy in Malaysian university English test (MUET) Writing. Creative Education, 7(04), 619. 